\title{
Limnology of shallow lakes of the semi-arid Central Pampa of Argentina
}

\author{
Limnologia de lagos rasos no Pampa semi-árido Central da Argentina
}

\author{
Santiago Andrés Echaniz ${ }^{1 *}$ (D) and Alicia María Vignatti ${ }^{1}$
}

${ }^{1}$ Facultad de Ciencias Exactas y Naturales, Universidad Nacional de La Pampa, Avenida Uruguay 151, 6300, Santa Rosa, La Pampa, República Argentina

*e-mail: santiagoechaniz@cpenet.com.ar

Cite as: Echaniz, S.A. and Vignatti, A.M. Limnology of shallow lakes of the semi-arid Central Pampa of Argentina. Acta Limnologica Brasiliensia, 2019, vol. 31, e11.

Abstract: Aim: The Central Pampa of Argentina has three recognized phytogeographic regions that arise due to the decrease in rainfall towards the west. The area has numerous lakes that are mainly temporary, with hydroperiods that relate to climatic cycles, although some of them have changed due to anthropogenic influence. Some of these lakes have been studied with special reference to zooplankton, but information on their physical and chemical aspects is scarce. Consequently, managing and evaluating the anthropogenic effects on these ecosystems is challenging. The objective of this study was to explore the limnological characteristics of lakes in different regions in the Central Pampa that experience different anthropic influences. Methods: Ten lakes were sampled seasonally (January, April, July, and October) during 2007. In situ measurements included transparency, $\mathrm{pH}$, temperature, and dissolved oxygen concentration, and 2-L water samples were collected to determine salinity, ion composition, suspended solids, nutrient concentration, and phytoplankton chlorophyll- $a$ concentration. Results: Salinity ranged from $0.32-136.72 \mathrm{~g} \mathrm{~L}^{-1}$, with $\mathrm{Na}^{+}$being the dominant ion in nine lakes and $\mathrm{Cl}^{-}$and $\mathrm{HCO}_{3}$ - predominating in the higher- and lower-salinity lakes respectively. Nutrient concentrations were high (total Kjeldahl nitrogen: 7.97-34.69 $\mathrm{mg} \mathrm{L}^{-1}$; total phosphorous: 4.07-14.82 $\mathrm{mg} \mathrm{L}^{-1}$ ), and all lakes were hypertrophic. We determined three lake classes: i) lakes transformed from low-salinity lakes into hypersaline ones through human inactivation of the fluvial system that fed it; ii) mesosaline temporary lakes lacking fish, with low concentrations of chlorophyll- $a$ and influenced by agricultural activities, and iii) subsaline and hyposaline lakes, highly modified by urban sewage, converted in permanent lakes (which allowed fish fauna development) and with reduced water transparency (due to high concentrations of phytoplankton chlorophyll- $a$ ). Conclusions: The chemical diversity of the studied lakes is low, and their predominance of $\mathrm{Na}^{+}$and $\mathrm{Cl}^{-}$indicated that evaporation and crystallization control the water chemistry. Additionally, this study showed the consequences of the anthropic impact, which alter water chemical composition, trophic structure and, thus, the ecological characteristics of lakes.

Keywords: Pampa, Argentina; water chemistry; saline lake; temporary lake; shallow lake; basin land use.

Resumo: Objetivo: No Pampa Central da Argentina, há três regióes fitogeográficas criadas pela diminuição da precipitação vinda do oeste. Essa região possui um grande número de lagos sendo a maioria desses temporários com hidroperíodos definidos por ciclos climáticos, embora alterados pela ação antrópica. Alguns desses lagos foram estudados com referência especial ao zooplâncton, apesar de que informaçóes básicas sobre aspectos físicos e químicos desses ambientes sejam escassas e dispersas. 
Em consequência, essa escassez de informações dificulta tanto a gestão quanto a avaliação de efeitos antrópicos sobre esses lagos. Este trabalho visou explorar e analisar as características limnológicas de lagos rasos de diferentes regióes do Pampa Argentino, os quais experimentam diferentes influências antrópicas. Métodos: Foram amostrados sazonalmente (janeiro, abril, julho e outubro) dez lagos em 2017. As medidas mensuradas incluíram transparência, pH, temperatura, concentração de oxigênio dissolvido, salinidade, composição iónica, sólidos em suspensão, concentração de nutrientes dissolvidos e concentração de clorofila- $a$. Resultados: A salinidade variou de 0.32 até 136.72 g. $\mathrm{L}^{-1}$. O Na $\mathrm{Na}^{+}$foi o íon dominante em nove lagos, e o $\mathrm{Cl}^{-}$e ${\mathrm{o} \mathrm{HCO}_{3}}_{3}$ predominaram nos lagos de maior e menor salinidade, respectivamente. As concentraçóes de nutrientes foram elevadas (TN: 7.97-34.69 $\mathrm{mg} \mathrm{L}^{-1}$; TP: 4.07-14.82 $\mathrm{mg} \mathrm{L}^{-1}$ ) e todos os lagos foram hipertróficos. Três classes de lagos foram estabelecidas: i) lagos transformados em hipersalinos pela influência antrópica, com elevadas concentraçóes de íons e alta transparência da água; ii) lagos mesosalinos temporários com influência de atividades agrícolas e com amplas variaçóes de salinidade. Esses carecem de peixes e, portanto, têm alta transparência e baixas concentraçôes de clorofila- $a$, e iii) lagos subsalinos e hiposalinos, altamente alterados por efluentes urbanos, o que os transformou em perenes. Nesses lagos está presente a ictiofauna, com predomínio de peixes planctívoros sendo sua transparência reduzida pelas altas concentraçóes de clorofila- $a$. Conclusóes: A diversidade química dos lagos estudados foi baixa e o domínio de $\mathrm{Na}^{+} \mathrm{e} \mathrm{Cl}^{-}$ indicam que a evaporação e cristalização, processos típicos em regióes áridas e semiáridas, controlam a química da água na maioria dos lagos. Este estudo mostrou a importância do impacto antrópico que levou desde a modificação da composição química da água até a mudança da estrutura trófica com a conseqüente alteraçáo das características ecológicas dos lagos.

Palavras-chave: Pampa Argentino; química da água; lago salino; lago temporário; lagos rasos; uso da terra.

\section{Introduction}

The central region of Argentina, where the province of La Pampa is located, is characterized by the predominance of semi-arid conditions that increase towards the west. This phenomenon arises due to a decreasing precipitation gradient that starts at $750 \mathrm{~mm} \mathrm{yr}^{-1}$ in the northeast and declines to less than $300 \mathrm{~mm} \mathrm{yr}^{-1}$ in the west (Roberto et al., 1994; Casagrande et al., 2006). These rainfall levels are surpassed by the annual potential evapotranspiration, which is close to $800 \mathrm{~mm} \mathrm{yr}^{-1}$ throughout the province (Ponce de León, 1998). One consequence of the region's semi-arid character is that rainfall shows a marked interannual variability, with wet or dry periods often lasting several years when the rainfall remains above or below the historical average (Viglizzo, 2010). This variation is attributed to the climatic phenomena of "El Niño", when rainfall increases, and "La Niña", when the opposite occurs and pronounced droughts ensue (Viglizzo, 2010; Dornes et al., 2016).

The area that comprises La Pampa consists of three phytogeographic regions, each with markedly different characteristics due to the east-west precipitation gradient. The first region, the Pampa Plains in the northeastern part of the province, receive high amounts of precipitation (Cabrera, 1976) (Figure 1). The relatively flat landscape and soft hills make this area the most fertile and productive in the province. It is also the area with the highest population density. The second region, the Thorny Forest in the central region of the province (Cabrera, 1976) (Figure 1), is characterized by a predominance of deciduous forests of "caldén" (Prosopis caldenia Burkart). In this region, large zones have been deforested for agricultural use, with cereal production and extensive cattle ranching predominating. The third region, the Monte in the western part of the province (Cabrera, 1976) (Figure 1), is characterized by low and dispersed vegetation, predominantly "jarillas" (Larrea spp.). This region has high aridity and a low population density, with agriculture consisting of extensive cattle, sheep, and goat production.

The Pampean territory has a large number of lakes, most of which are temporary and are generally located in arheic basins. During wet cycles, they can be filled within a short time, with drying times depending on their extension; the larger lakes may contain water for several years. These lakes have been the subject of numerous studies that have mainly focused on the ecological aspects of the zooplankton communities. However, information on the environmental parameters of these lakes has often only been briefly described (Del Ponti et al., 2015; Echaniz \& Vignatti, 2010, 2011, 2013; Echaniz et al., 2006; 2008, 2009, 2012, 2015a,b; Vignatti et al., 2007, 2012, 2013, 2016). Consequently, data on physical and chemical characteristics of these lakes are either nonexistent or relatively scarce. 


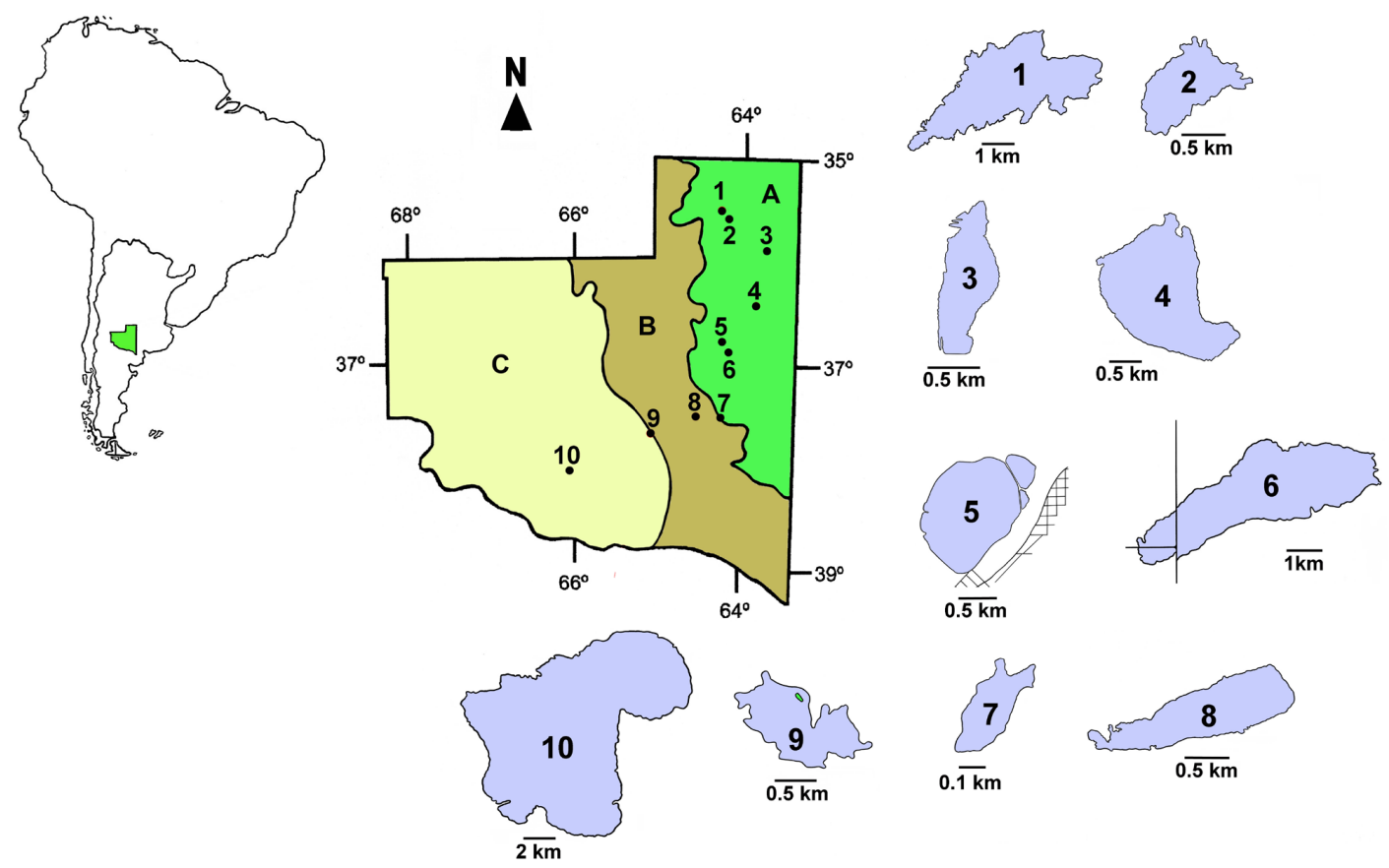

Figure 1. Geographic location of the 10 studied lakes of the semi-arid Central Pampa in Argentina. 1: CHA; 2: EPM; 3: LAR; 4: ESJ; 5: DTO; 6: BGI; 7: OPB; 8: UTR; 9: ECA, and 10: LAM. Phytogeographical regions of the Pampa Plains (region A), Thorny Forest (B), and Monte (C).

The amounts of solutes and the proportions of the major ions are highly variable in epicontinental aquatic ecosystems (Kalff, 2002) and they are aspects that depend on factors such as the geographic location, type of basin, nature of the soils, origin of the water, and the influence of human activities on their catchment basins (Wetzel, 2001). The little-known aspects of the lakes of La Pampa include, in particular, the ionic composition of the water and the mechanisms that govern water chemistry. Similarly, information on nutrient concentrations and trophic status is scarce, with only one known data synthesis (Echaniz \& Vignatti, 2013).

In addition, different anthropic impacts, related with their geographic locations and the differences in land use in their basins, have occurred on pampean lakes; however, no information is available regarding the drastic changes experienced by several lakes, especially those nearest cities. These lakes are subjected to human activities, such as the operation of pluvial or sewage drains or the interruption of water flow by the construction of reservoirs in fluvial systems. Similarly, information on the consequences of the introduction of exotic fish and their biotic interactions and the resulting changes in the limnological characteristics of several lakes where this phenomenon has been observed is lacking.
This lack of background information makes difficult a broad range of studies, such as ecological comparisons, planning management strategies for lakes of particular importance, the determination of the effects of land use changes on their basins or that of alterations in their feeding mechanisms. Other studies that are hampered by the lack of basic information are that destined to know the ecological changes produced by the introduction of fish, the determination of the effects of climate change, or the rise in salinity (Dokulil, 2016); the last is an important phenomenon in the arid diagonal of Argentina (D'Ambrosio et al., 2016). Therefore, the objective of the present work was to characterize the abiotic and biotic characteristics of aquatic ecosystems located in different geographic regions of La Pampa that differ in anthropic pressures and to analyze the relationships between lake physico-chemical parameters and the consequences of human activities in the central part of La Pampa.

\section{Materials and Methods}

\subsection{Study area}

We studied 10 lakes located in the three phytogeographic regions in the province of La Pampa (Table 1 and Figure 1). Three of these 
Table 1. Name, acronym, geographical location, and main morphometric parameters of the 10 studied lakes of the semi-arid Central Pampa in Argentina, sampled during 2007.

\begin{tabular}{lcccccc}
\hline \multicolumn{1}{c}{ Lake } & & $\begin{array}{c}\text { Geographical } \\
\text { location }\end{array}$ & $\begin{array}{c}\text { Maximum } \\
\text { length }(\mathbf{m})\end{array}$ & $\begin{array}{c}\text { Maximum } \\
\text { width }(\mathbf{m})\end{array}$ & Area (ha) & $\begin{array}{c}\text { Maximum } \\
\text { depth }(\mathbf{m})\end{array}$ \\
\hline Chadilauquen & CHA & $64^{\circ} 19^{\prime} \mathrm{O} 35^{\circ} 24^{\prime} \mathrm{S}$ & 6,391 & 2,739 & 893.21 & 2.20 \\
Estancia Pey-Ma & EPM & $64^{\circ} 15^{\prime} \mathrm{O} 35^{\circ} 26^{\prime} \mathrm{S}$ & 1,326 & 682 & 62.80 & 2.10 \\
Estancia San José & ESJ & $63^{\circ} 55^{\prime} \mathrm{O} 36^{\circ} 21^{\prime} \mathrm{S}$ & 2,628 & 1,923 & 288.53 & 2.47 \\
Ojo agua Padre Buodo & OPB & $64^{\circ} 17^{\prime} \mathrm{O} 37^{\circ} 14^{\prime} \mathrm{S}$ & 411 & 165 & 4.60 & 2.23 \\
Utracán & $\mathrm{UTR}$ & $64^{\circ} 36^{\prime} \mathrm{O} 37^{\circ} 17^{\prime} \mathrm{S}$ & 2,333 & 649 & 96.61 & 2.20 \\
El Carancho & $\mathrm{ECA}$ & $65^{\circ} 03^{\prime} \mathrm{O} 37^{\circ} 27^{\prime} \mathrm{S}$ & 1,670 & 842 & 85.10 & 1.61 \\
La Amarga & LAM & $66^{\circ} 07^{\prime} \mathrm{O} 38^{\circ} 13^{\prime} \mathrm{S}$ & 15,428 & 9,688 & 11,109 & 12.00 \\
La Arocena & LAR & $63^{\circ} 42^{\prime} \mathrm{O} 35^{\circ} 40^{\prime} \mathrm{S}$ & 1,446 & 512 & 48.52 & 3.20 \\
Don Tomás & DTO & $64^{\circ} 19^{\prime} \mathrm{O} 36^{\circ} 37^{\prime} \mathrm{S}$ & 1,745 & 1,167 & 148.32 & 2.31 \\
Bajo de Giuliani & $\mathrm{BGI}$ & $64^{\circ} 15^{\prime} \mathrm{O} 36^{\circ} 41^{\prime} \mathrm{S}$ & 7,600 & 2,543 & $1,171.31$ & 2.80 \\
\hline
\end{tabular}

lakes -Chadilauquen (CHA), Estancia Pey-Ma (EPM), and Estancia San José (ESJ)- are located in the north of the province in the region of the Pampa Plains (Cabrera, 1976) (Figure 1). They are embedded in a landscape with gentle undulations and are surrounded by agricultural fields (mainly used for cereal and soy production). During the study period, fish fauna and aquatic vegetation were lacking. Crustaceans predominated in the zooplankton, especially the calanoid Boeckella poopoensis Marsh, 1906 and the cladoceran Moina eugeniae Olivier, 1954. CHA supported another cladoceran, Daphnia menucoensis Paggi, 1996. All three lakes were inhabited by flamingos (Phoenicopterus chilensis Molina, 1782). In addition, in ESJ, white-necked swans (Coscoroba coscoroba Molina, 1782) and Baird's sandpipers (Calidris bairdii Coves, 1861) were frequently found, and some brown-hooded gulls (Larus maculipennis Lichtenstein, 1823) were occasionally observed.

Another three lakes -Ojo de agua Padre Buodo (OPB), Utracan (UTR), and El Carancho (ECA)- are located in the center of the province in the dune chains of the valleys of Utracan and Argentino (Figure 1). The first lake lies in the ecotone between the Pampa Plains and the Thorny Forest, the second lies in the center of the belt of the Thorny Forest, and the third lies in the ecotone between this region and the Monte (Cabrera, 1976). These lakes are surrounded by natural vegetation, and extensive livestock agriculture is practiced in their basins. OPB lacked aquatic vegetation but presented a population of carp (Cyprinus carpio Linnaeus, 1758) and small-sized zooplankton, with a predominance of rotifers, especially Keratella tropica (Apstein, 1907). Conversely, UTR and ECA presented variable coverages of the macrophyte Ruppia cirrhosa Petagna
Grande, had no fish fauna, and their zooplankton community was dominated by $B$. poopoensis, $D$. menucoensis, and $M$. eugeniae. The avifauna of ECA was relatively rich, with the presence of black-necked swans (Cygnus melancoryphus Molina, 1782), white-necked swans, and shorebirds, such as "teros" (Vanellus chilensis Molina, 1782) or Azara’s sandpipers (Charadrius collaris Vieillot, 1818). Occasionally, ducks (Anas sp.) and white-winged coots (Fulica leucoptera Vieillot, 1817) were sighted. All these lakes are temporary, shallow (Table 1), and fed by rainfall and groundwater (Dornes et al., 2016). They are located in arheic basins, and therefore water losses are mainly due to evaporation.

Lake La Amarga (LAM) is situated in the Monte region (Cabrera, 1976) and is surrounded by natural vegetation with a predominance of "jarillas" (Larrea spp.). This lake differs from the previous six in that it was a permanent lake in the past, but it is currently a semi-permanent lake and its salinity is usually high. Flamingos were observed on all occasions, and its zooplankton consisted only of the anostraca Artemia persimilis Piccinelli and Prosdocimi, 1968. The region's low rainfall, which is approximately $350 \mathrm{~mm} \mathrm{yr}^{-1}$ (Casagrande et al., 2006), limits human activity to goat rearing.

The remaining three lakes are La Arocena (LAR), located $4 \mathrm{~km}$ from the city of General Pico, and Don Tomas (DTO) and Bajo de Giuliani (BGI), located to the west and $10 \mathrm{~km}$ to the south of Santa Rosa (the capital city), respectively (Figure 1). These lakes differ from the other seven because they serve as receivers of storm drains. In addition, BGI receives the entire sewage waste from Santa Rosa. The result is that these lakes are currently permanent, which has allowed the establishment of a fish fauna consisting predominantly of silversides (Odonthestes bonariensis Valenciennes, 1835). 
The presence of piscivorous birds is common, with cormorants (Phalacrocorax brasilianus Gmelin, 1789) being prominent. The zooplankton of these lakes is relatively small in size, with a predominance of cyclopoid copepods and rotifers.

\subsection{Field work}

Seasonal sampling was carried out four times (January, April, July, and October) throughout 2007. Summer sampling in ECA was performed in early February, as the lake was dry until filled with water from torrential rains after January 26th.

In situ measurements included water transparency (using a Secchi disc), $\mathrm{pH}$ (using a Corning $^{\circledR}$ PS-15 peachimeter), water temperature, and dissolved oxygen (using a Lutron ${ }^{\circledR}$ DO 5510 oximeter). In the central zone of each lake, 2-L water samples were collected at a depth of $0.5 \mathrm{~m}$ to determine salinity, ion composition, suspended solids, nutrient concentration, and phytoplankton chlorophyll-a concentration. These samples were kept in the dark and refrigerated until analyses were performed.

Zooplankton samples were obtained using vertical and horizontal trawls with a net of $22 \mathrm{~cm}$ in diameter and a $40-\mu \mathrm{m}$ pore aperture. The collected organisms were anaesthetized with $\mathrm{CO}_{2}$ and then fixed with 5\% formalin. The presence of fish was assessed using trawls and traps, and the specimens collected were preserved in formaldehyde. When aquatic vegetation was present, its location and approximate percentage of coverage were visually determined, and samples were taken for identification.

\subsection{Laboratory work}

Total dissolved solids (TDS) were measured using the gravimetric method by drying $50 \mathrm{~mL}$ of pre-filtered $(1 \mu \mathrm{m}$ pore Microclar FFG047WPH glass fiber filters) water at $104{ }^{\circ} \mathrm{C}$ to a constant weight. The ionic content of the water was determined according to standardized routines: $\mathrm{Na}^{+}$(selective ion electrode); $\mathrm{K}^{+}$(determination of the intensity of the turbidity by the combination of potassium with sodium tetraphenylborate); $\mathrm{Ca}^{2+}$ (EDTA digital titulometric method or spectrophotometric method in the case of very low calcium levels); $\mathrm{Mg}^{2+}$ (digital titrometric method or spectrophotometric method in the case of very low magnesium levels); $\mathrm{Cl}^{-}$(argentometric method [digital titration with silver nitrate solution in the presence of potassium chromate] or the spectrophotometric method in cases where the concentration of this ion was very low); $\mathrm{SO}_{4}^{2-}$ (spectrophotometric determination of the intensity of the turbidity formed during the reaction of the sulfate with barium); and $\mathrm{HCO}_{3}^{-}$and $\mathrm{CO}^{2-}$ (alkalinity method of phenolphthalein and digital titration) (APHA, 1992). Total suspended solids (TSS), organic suspended solids (OSS), and inorganic suspended solids (ISS) were determined by filtration through $1 \mu \mathrm{m}$ pore Microclar FFG047WPH glass fiber filters of $47 \mathrm{~mm}$ in diameter. The filters were washed and weighed, dried to a constant weight at $103-105^{\circ} \mathrm{C}$, and calcined at 550-600 ${ }^{\circ} \mathrm{C}$ (EPA, 1993). Total Kjeldahl nitrogen concentration (TKN) was determined using the Kjeldahl method, and total phosphorous (TP) concentration was analysed by acid digestion with potassium persulfate and subsequent determination in spectrophotometer. Chlorophyll- $a$ concentration (Chl-a) was estimated by filtration through $1 \mu \mathrm{m}$ pore Microclar FFG047WPH glass fiber filters, extraction with aqueous acetone, and determination by spectrophotometry with a Metrolab 1700 spectrophotometer (Arar, 1997).

\subsection{Quantitative data analysis}

We used the lake classification scheme based on salinity proposed by Hammer (1986). Descriptive statistics (Sokal \& Rohlf, 1995; Zar, 1996) and principal component analysis (PCA) (Perez, 2004) were performed to explore the physico-chemical characteristics of the lakes. Groupings of lakes according to their environmental variables were established using Gower's cluster analysis (Perez, 2004).

The mean annual concentrations of the major ions were represented using Maucha schemes with the modification proposed by Broch \& Yake (1969); thus, the surfaces of the central circles were proportional to the total amounts of ions and the different sizes of colorful areas represent ion concentration.

The mechanisms that govern the chemical composition of waters were examined by calculating the relationships between $\mathrm{Na}^{+} / \mathrm{Na}^{+}+\mathrm{Ca}^{2+}$ and $\mathrm{Cl}^{-} / \mathrm{Cl}^{-}+\mathrm{HCO}_{3}^{-}$and plotting the results in boomerang-shaped graphs. When the results of the calculations fall on the lower arm of the boomerang, it indicates that the mechanism that determines the chemistry of water is atmospheric precipitation. If they fall on the central zone it indicates the dominance of the rocks, whereas if they fall on the upper arm of the boomerang it indicates the predominance of evaporation-precipitation 
processes (Gibbs, 1970; Drago \& Quirós, 1995; Wetzel, 2001; Fernández Cirelli \& Miretzky, 2004). We used Infostat (Di Rienzo et al., 2010) and PAST software (Hammer et al., 2001) for analyses.

\section{Results}

Mean water temperature ranged between $14.58{ }^{\circ} \mathrm{C}( \pm 7.99)(\mathrm{LAM})$ and $17.58^{\circ} \mathrm{C}( \pm 7.43)$ (LAR). This parameter followed a similar seasonal pattern in all lakes, with winter temperatures below $5^{\circ} \mathrm{C}$ in $\mathrm{OPB}$ and $\mathrm{ESJ}$ to slightly above $8^{\circ} \mathrm{C}$ in EPM. Summer temperatures were close to $22^{\circ} \mathrm{C}$ (ECA) and $29^{\circ} \mathrm{C}(\mathrm{OPB})$. The spring temperature in LAM was more than $8{ }^{\circ} \mathrm{C}$ lower than in the rest of the lakes (Figure 2a and Table 2).

Mean salinity ranged between $0.38 \mathrm{~g} \mathrm{~L}^{-1}( \pm 0.08)$ (LAR) and $115.51 \mathrm{gL}^{-1}( \pm 19.02)(\mathrm{LAM})$. The absolute values ranged from a minimum of 0.32 to a maximum of $136.72 \mathrm{~g} \mathrm{~L}^{-1}$, registered during autumn in LAR and LAM, respectively (Table 2). No seasonal pattern was detected, but relatively wide variations involving declines could be observed in some lakes, such as those observed at EPM, where salinity decreased from $48.31 \mathrm{~g} \mathrm{~L}^{-1}$ (January) to $31.22 \mathrm{~g} \mathrm{~L}^{-1}$ (October), and at LAM, where salinity ranged from $90.52 \mathrm{~g} \mathrm{~L}^{-1}$ (October) to $136.69 \mathrm{~g} \mathrm{~L}^{-1}$ (April).
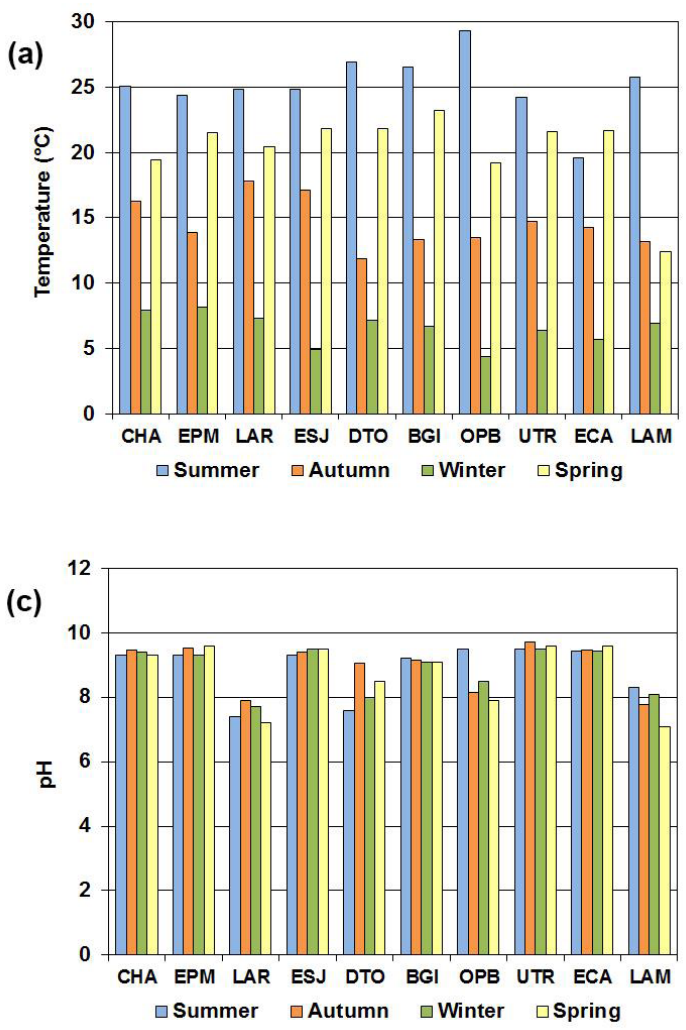

Conversely, ECA showed an increase, with the minimum value $\left(5.70 \mathrm{~g} \mathrm{~L}^{-1}\right)$ recorded immediately after the filling (February); this value then increased to a maximum of $15.12 \mathrm{~g} \mathrm{~L}^{-1}$ (October) (Figure 2b and Table 2).

The mean $\mathrm{pH}$ was relatively different among the lakes, ranging from a minimum of $7.55( \pm 0.31)$ (LAR) to a maximum of $9.58( \pm 0.10)$ (UTR) (Table 2). This parameter showed no pattern of seasonal variation, and it was greater than 9.00 on all occasions in CHA, EPM, ESJ, BGI, UTR, and ECA, whereas it never exceeded 8.50 in the other four lakes (Figure 2c).

The mean concentrations of dissolved oxygen ranged from a minimum of $5.88 \mathrm{mg} \mathrm{L}^{-1}( \pm 3.03)$ (EPM) to a maximum of $14.13 \mathrm{mg} \mathrm{L}^{-1}( \pm 3.61)$ (BGI) (Table 2). Dissolved oxygen did not show any defined seasonal pattern, and the levels generally exceeded $7.00 \mathrm{mg} \mathrm{L}^{-1}$. The exception was EPM, which showed lower amounts, especially during spring $\left(2.41 \mathrm{mg} \mathrm{L}^{-1}\right)$. The maximum concentration was recorded in BGI in summer $\left(18.42 \mathrm{mg} \mathrm{L}^{-1}\right)$ (Figure 2d).

Analysis of the ionic composition showed $\mathrm{Na}^{+}$as the dominant cation in nine lakes, representing almost $80 \%$ of the total cations
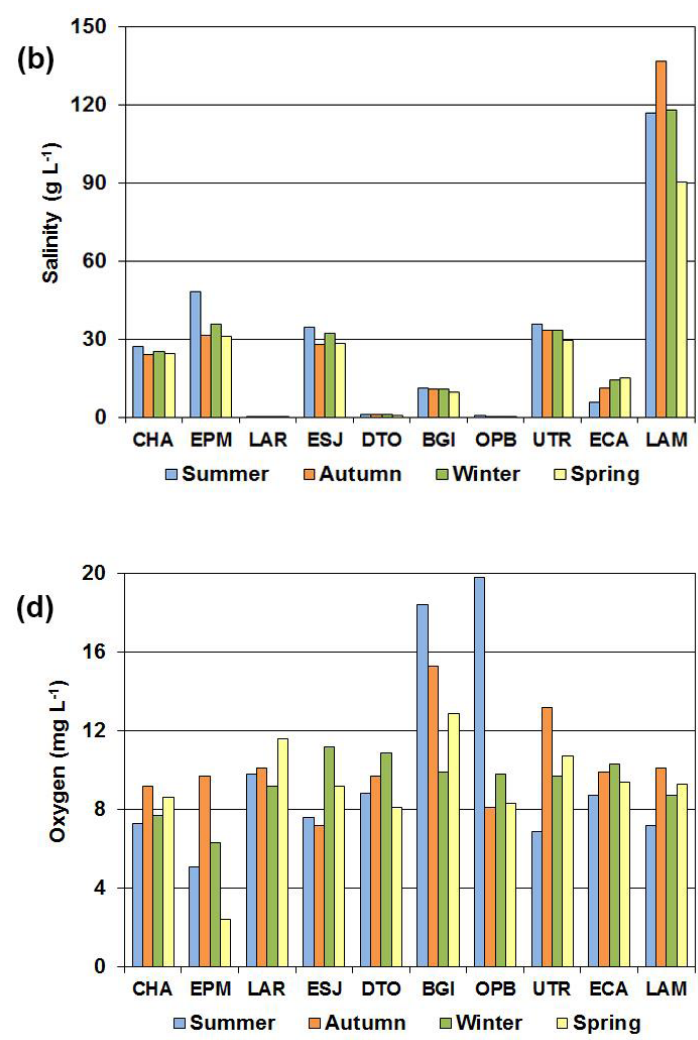

Figure 2. Seasonal variation of the water temperature (a), salinity (b), $\mathrm{pH}$ (c), and dissolved oxygen (d) of the 10 studied lakes in the semi-arid Central Pampa in Argentina in 2007. 


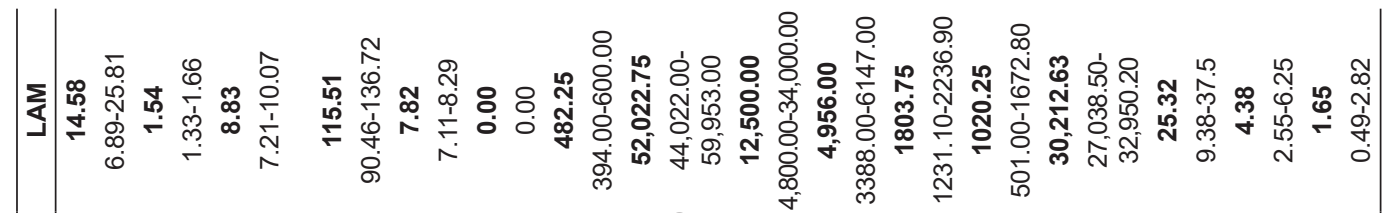

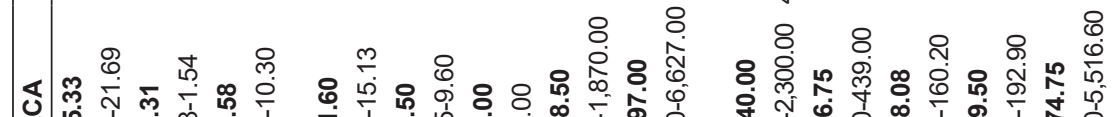

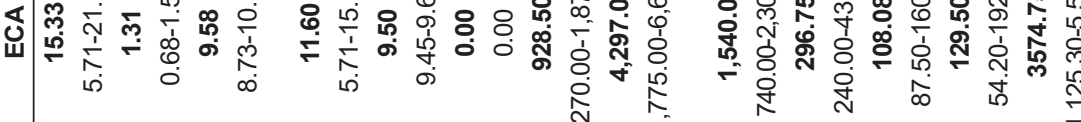

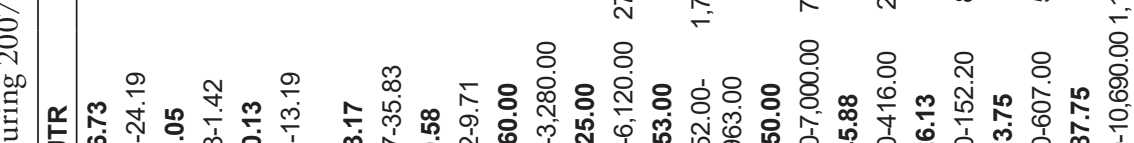

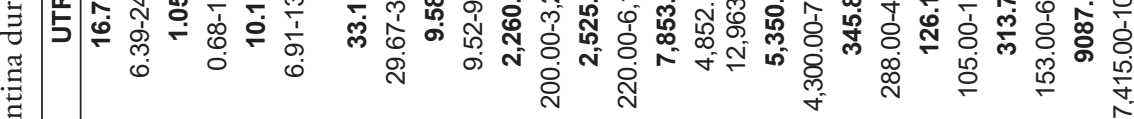

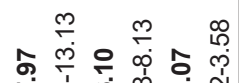

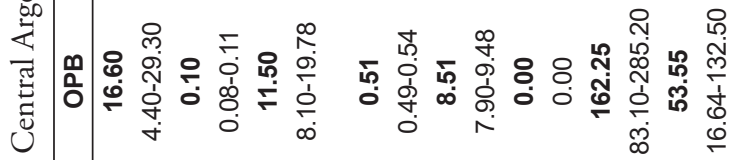

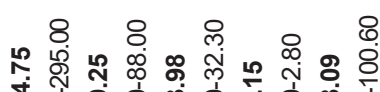
竎 त

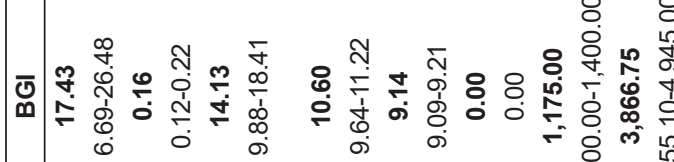

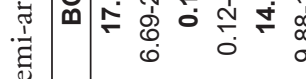

ક્

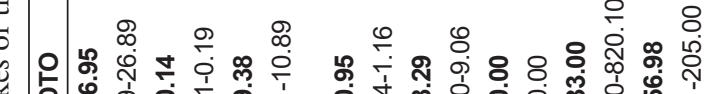
㞼

ᄂ

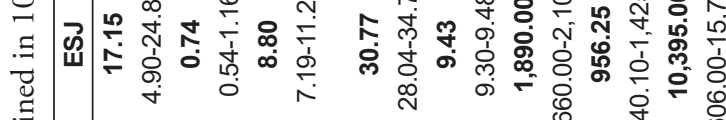
少

崩 岛

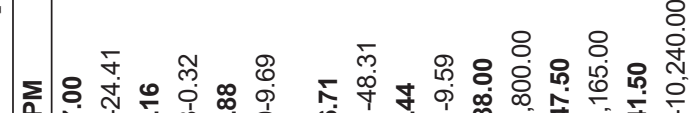
苞

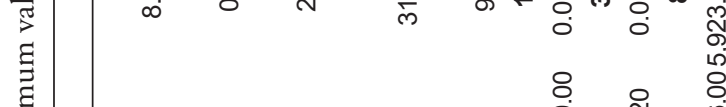
药

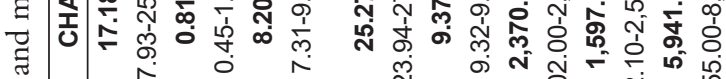

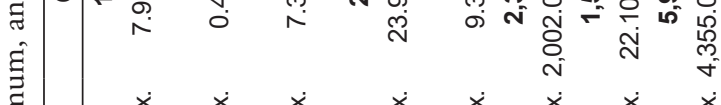

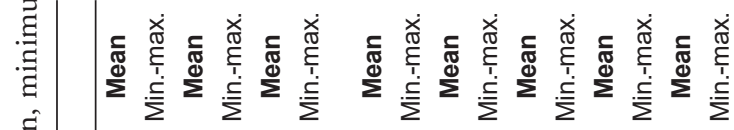

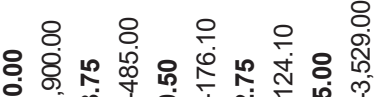

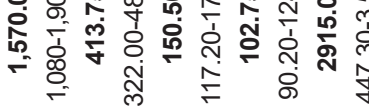
ผ ఊั ठิ \& 8 i

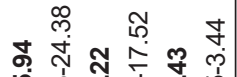

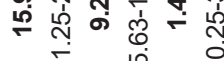

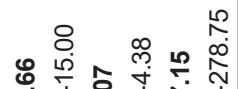

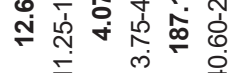
\& 8 : ถุ่

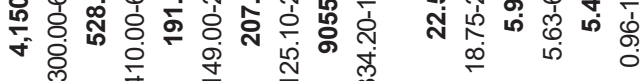

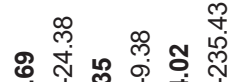

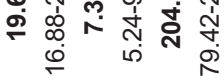

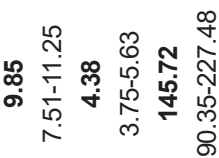

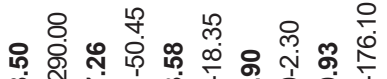

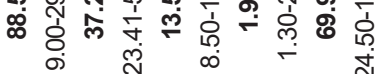

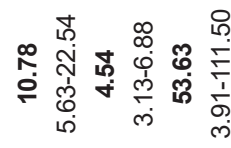

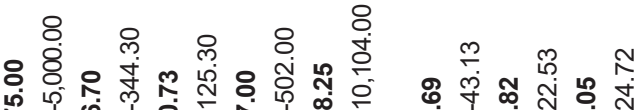
万্ল N n n n

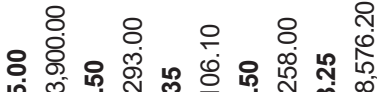

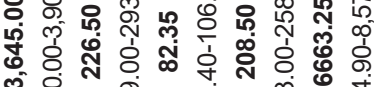

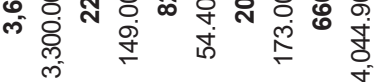

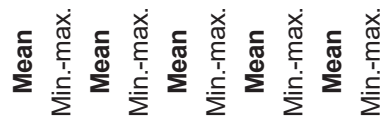

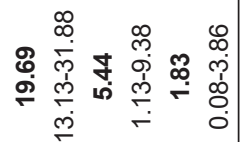

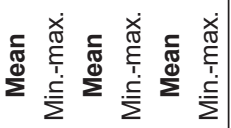

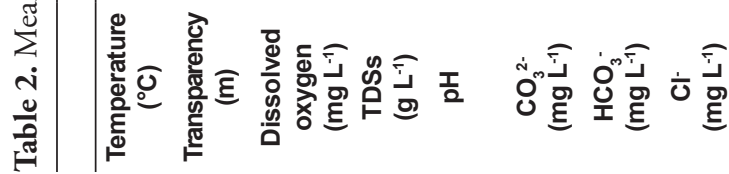

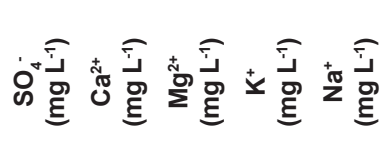

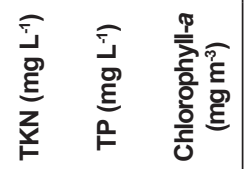




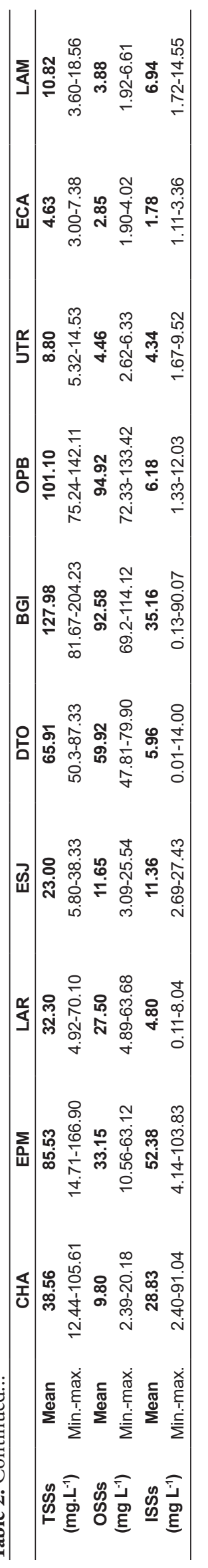


(Figure 3 and Table 2). The $\mathrm{Na}^{+}$concentration fluctuated widely, from a minimum of $24.50 \mathrm{mg}$ $\mathrm{L}^{-1}$ in LAR to $32,950.00 \mathrm{mg} \mathrm{L}{ }^{-1}$ in LAM. $\mathrm{Ca}^{2+}$ concentrations represented a high percentage of cations $(30.4 \%)$ in LAR but less than $13 \%$ in the rest of the lakes (Figure 3 and Table 2). The concentrations of $\mathrm{Mg}^{2+}$ had relatively high percentages only in LAR (11.1\%) and OPB (14.7\%), and the concentrations of $\mathrm{K}^{+}$did not exceed $3.5 \%$ of the total of the cations in any lake (Figure 3 and Table 2).

A greater variation was recorded for anions. The $\mathrm{Cl}^{-}$was the dominant anion in the high-salinity lakes. Its concentration varied widely, from $16.60 \mathrm{mg} \mathrm{L}^{-1}$ measured in OPB to $59,953.00 \mathrm{mg} \mathrm{L}^{-1}$ in LAM (Figure 3 and Table 2). The $\mathrm{HCO}_{3}{ }^{-}$predominated in lakes with low salinity and therefore in LAR and DTO represented $72.4 \%$ and $50.6 \%$ of the total anions, respectively (Figure 3 and Table 2). The $\mathrm{SO}_{4}^{2-}$ represented higher percentages in DTO (31.1\%), OPB (36.6\%), and UTR (29.7\%) (Figure 3 and Table 2). $\mathrm{CO}_{3}{ }^{2-}$ was recorded only in the four mesosaline lakes and was undetectable in the other five lakes (Figure 3 and Table 2).

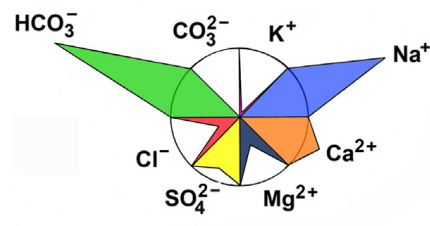

LAR

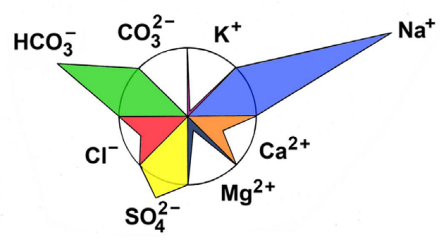

DTO

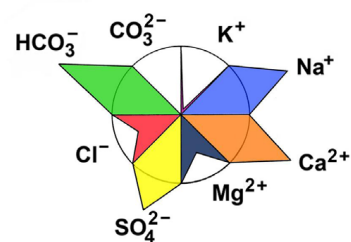

OPB
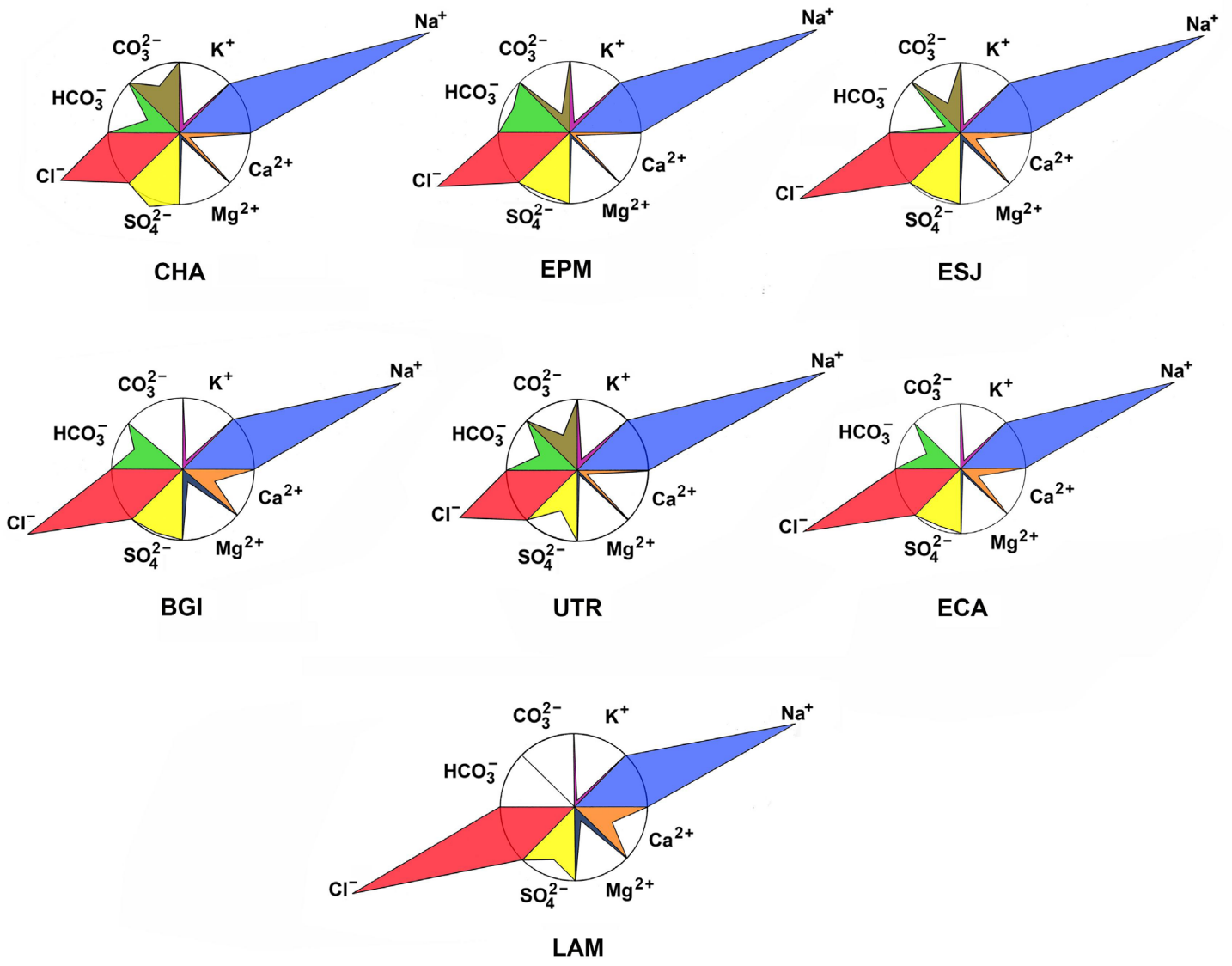

Figure 3. Water ionic composition of the 10 studied lakes in the semi-arid Central Pampa in Argentina during 2007, presented using Maucha scheme. The different sizes of colorful areas represent ion concentration (annual mean values). The scale differs: the diameter of the central circle indicates $1,239 \mathrm{mg} \mathrm{L}^{-1}$ for LAR, DTO, and OPB; $2,786 \mathrm{mg} \mathrm{L}^{-1}$ for CHA, EPM, ESJ, BGI, UTR, and ECA; and 10,299 $\mathrm{mg} \mathrm{L}^{-1}$ for LAM. 

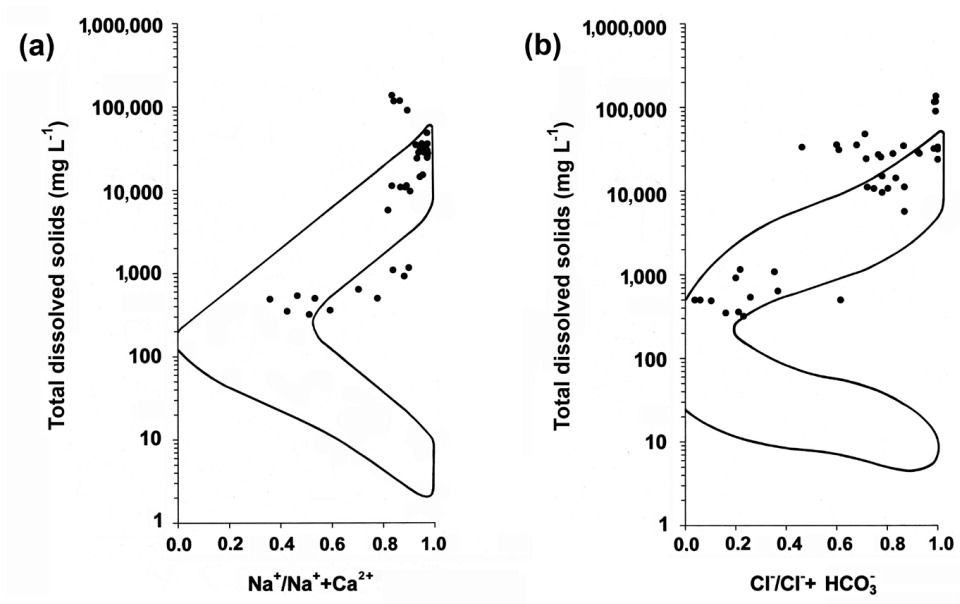

Figure 4. Relationships between $\mathrm{Na}^{+} / \mathrm{Na}^{+}+\mathrm{Ca}^{2+}$ (a) and $\mathrm{Cl}^{-} / \mathrm{Cl}^{-}+\mathrm{HCO}_{3}^{-}$(b) determined in 10 studied lakes of the semi-arid Central Pampa in Argentina in 2007.

The calculation of the relationship between $\mathrm{Na}^{+} / \mathrm{Na}^{+}+\mathrm{Ca}^{2+}$ (Figure $4 \mathrm{a}$ ) yielded values that exceeded 0.90 for the high-salinity lakes, given the predominance of $\mathrm{Na}^{+}$. Therefore, the points corresponding to the different samples were placed in the upper right sector of the Gibbs boomerang-shaped graph. The LAM points were slightly higher, given the lake's high TDS concentrations (Figure 4a). The lakes with lower salinity (TDS $<1000 \mathrm{mg} \mathrm{L}^{-1}$ ) showed values that ranged from 0.36 to $0.53(\mathrm{OPB}), 0.43$ to 0.78 (LAR), and 0.70 to 0.90 (DTO), with points in the intermediate zone of the Gibbs boomerang (Figure 4a).

The relationship between $\mathrm{Cl}^{-} / \mathrm{Cl}^{-}+\mathrm{HCO}_{3}{ }^{-}$ showed the same groupings of points, and the samples corresponding to the highest salinity lakes showed values higher than 0.75 , given the predominance of $\mathrm{Cl}^{\text {- The }}$. The were located in the upper right corner of the corresponding boomerang, while the samples of lakes with lower concentrations of TDSs (LAR, DTO, and OPB) showed ratios below 0.37 , due to the predominance of $\mathrm{HCO}_{3}$. Therefore, the points were located near the central region of the graph (Figure $4 \mathrm{~b}$ ).

The amounts of TSS varied widely among the lakes. The minimum, close to $5.00 \mathrm{mg} \mathrm{L}^{-1}$, was registered in ECA and the maximum, close to $130.00 \mathrm{mg} \mathrm{L}^{-1}$, in BGI (Table 2).

OSS values were higher in LAR, DTO, BGI, and $\mathrm{OPB}$, where they always exceeded $70 \%$ of the total suspended solids, and a certain seasonal pattern could be distinguished because, with the exception of EPM and BGI, OSS concentrations were higher in summer in the rest of the lakes
(Figure 5a and Table 2). The ISS were more abundant in CHA, EPM, and LAM, where they exceeded $60 \%$ of the total suspended solids, whereas in UTR and ESJ, both fractions were recorded in relatively similar proportions (Table 2). The ISS show a certain seasonality because in three lakes (CHA, EPM, and UTR) were higher in winter, whereas in six lakes (LAR, ESJ, DTO, BGI, OPB, and LAM) were higher in spring. Only in ECA were the ISS higher in summer (Figure $5 b$ ).

Nutrient concentrations in water were relatively high in all lakes. The mean values of TKN varied widely, ranging from a maximum of $34.69 \mathrm{mg} \mathrm{L}^{-1}( \pm 6.22)$ in EPM to a minimum of $7.97 \mathrm{mg} \mathrm{L}^{-1}( \pm 3.54)$ in ECA (Table 2). A certain pattern of seasonal variation was found, as TKN concentrations were higher in winter in seven lakes (LAR, ESJ, BGI, OPB, UTR, ECA, and LAM), whereas the minimum was found in summer in five lakes (LAR, ESJ, BGI, UTR, and ECA) and in autumn in four lakes (EPM, DTO, OPB, and LAM) (Figure 5c).

The highest mean concentration of TP (14.82 $\left.\mathrm{mg} \mathrm{L}^{-1} \pm 9.76\right)$ was recorded in EPM (Table 2), and the minimum was recorded in OPB ( $4.07 \mathrm{mg} \mathrm{L}^{-1} \pm 0.36$ ). It was not possible to discern a seasonal variation pattern (Figure $5 \mathrm{~d}$ ).

Water transparency fluctuated widely among the 10 lakes. Mean transparency was reduced and was almost always less than $0.20 \mathrm{~m}$ in EPM, DTO, BGI, and OPB. By contrast, transparency was higher, although variable, in CHA, ESJ, UTR, ECA, and LAM (Table 2). This parameter showed certain seasonality, with higher values during autumn in 

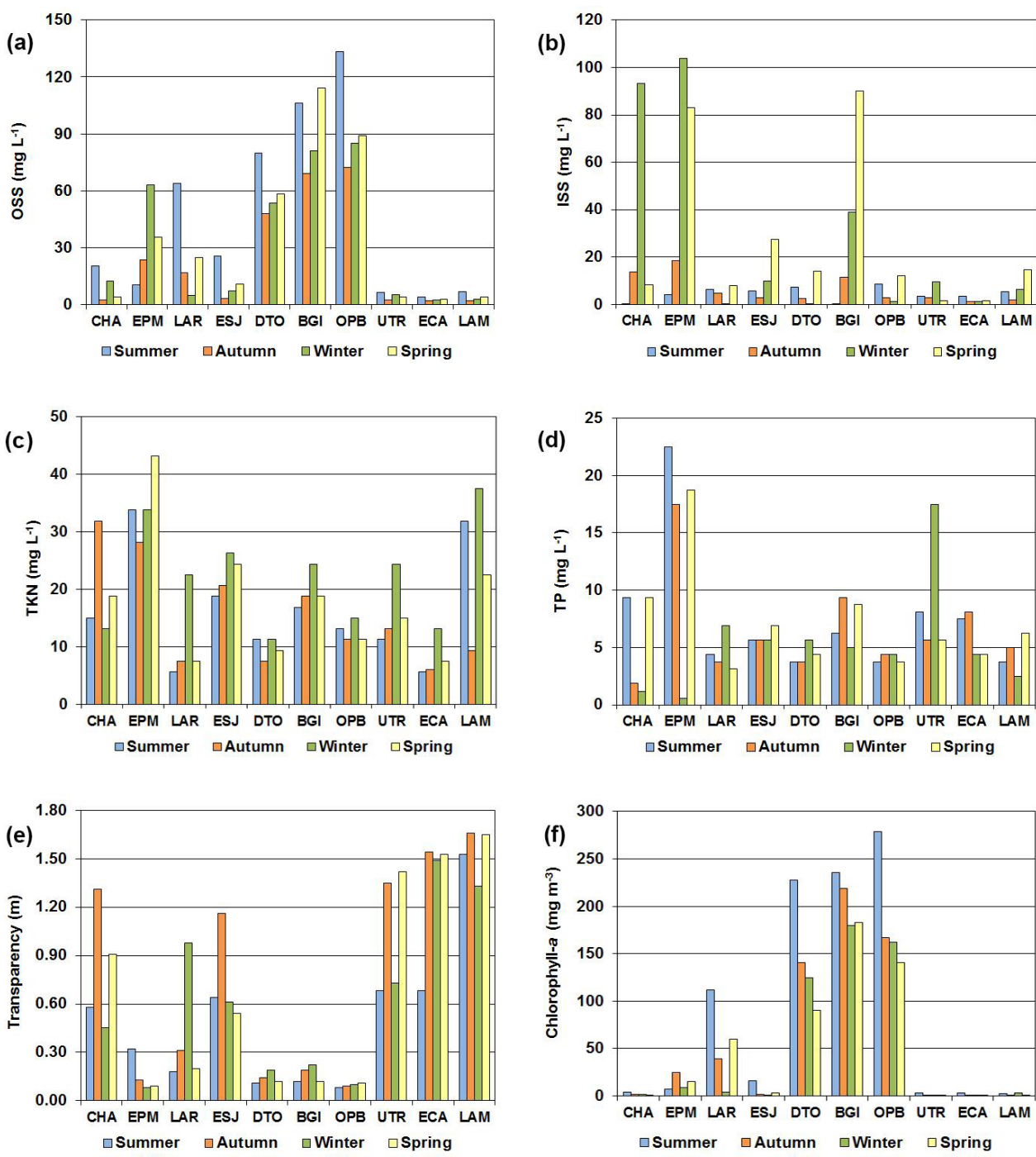

Figure 5. Seasonal variation of organic suspended solids (a), inorganic suspended solids (b), total Kjeldahl nitrogen (c), total phosphorous (d), water transparency (e), and phytoplankton chlorophyll-a concentration (f) of 10 studied lakes of the semi-arid Central Pampa in Argentina during 2007.

CHA, ESJ, and LAR and during winter in LAR, DTO, and BGI (Figure 5e).

The concentration of phytoplankton chlorophyll- $a$ also varied widely among the lakes, and two groups of lakes could be recognized. The first group (DTO, OPB, and BGI) showed concentrations above $140.00 \mathrm{mg} \mathrm{m}^{-3}$, and the second (CHA, LAR, ESJ, UTR, ECA, and LAM) showed concentrations below $55.00 \mathrm{mg} \mathrm{m}^{-3}$ (Table 2). The lakes with the highest concentrations of chlorophyll- $a$ had lower water transparency; however, EPM was an exception, as it showed reduced transparency but relatively low chlorophyll- $a$ concentrations (Table 2). This measure showed a strong seasonality because, with the exception of EPM, the highest concentrations were registered during the summer (Figure 5f).
Based on all the measured environmental variables, the lakes were categorized into three types. The first was the hypersaline type (Figure 6, black), such as LAM, which had high concentrations of ions and nutrients but high water transparency. The second was the mesosaline type (Figure 6, blue), which had relatively clear water (ESJ, CHA, UTR, and ECA); EPM was also incorporated into this group given its common chemical characteristics, despite the low transparency caused by ISS. The third was the turbid type (Figure 6, red), which shared the characteristic of reduced water transparency due to the high concentrations of chlorophyll- $a$ and OSS; this type included both the subsaline lakes (LAR, DTO, and OPB) and the hyposaline lakes (BGI). 
The PCA analysis, the first two components of which explained more than $70 \%$ of the variance, showed the importance of salinity on one hand and of the concentrations of OSS and chlorophyll- $a$ on the other in the determination of the characteristics of the lakes of Central Pampa, given the high correlations between these parameters and component 1 (Figure 7).
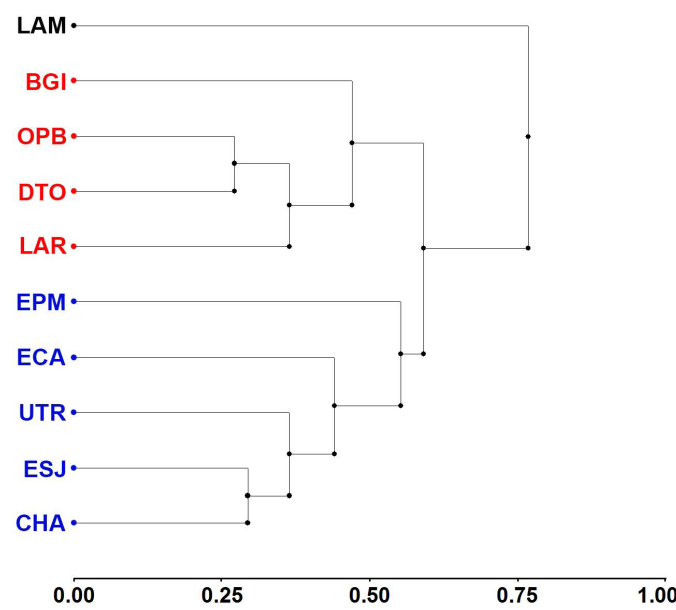

Figure 6. Grouping of the 10 studied lakes of the semi-arid Central Pampa in Argentina, based on the physico-chemical parameters determined during 2007.

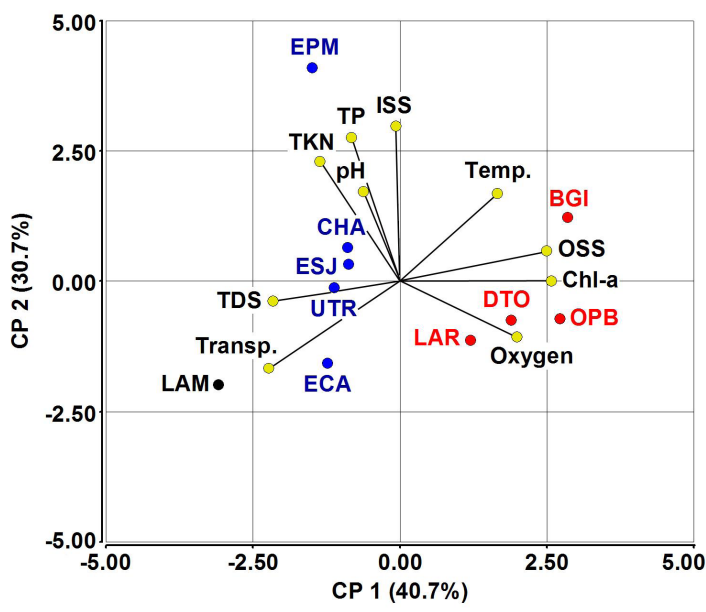

Figure 7. Box plot of principal component analysis of the 10 studied lakes of the semi-arid Central Pampa in Argentina, based on the physico-chemical parameters determined during 2007. ISS: inorganic suspended solids. TP: total phosphorous. TKN: total Kjeldahl nitrogen. $\mathrm{pH}$ : hydrogen potential. Temp.: water temperature. OSS: organic suspended solids. Chl-a: phytoplankton chlorophyll-a concentration. Oxygen: dissolved oxygen concentration. TDS: total dissolved solids. Transp.: water transparency. CP 1: first principal component. CP 2: second principal component.
This analysis corroborated the groupings of lakes shown by clustering analysis. Furthermore, given the high correlation between the ISS and component 2 , it showed the importance of inorganic turbidity in the structuring of lakes, such as EPM (Figure 7).

\section{Discussion}

The rainfall in the Central Pampa of Argentina shows a marked interannual variability that arises from the alternation of the climatic phenomena of "El Niño" and "La Niña" (Viglizzo, 2010). This fluctuation has a significant influence on the ecology of the region's aquatic ecosystems, since it renders them temporary, with hydroperiods related to those climatic cycles. The feeding of most of the shallow lakes of La Pampa depends on rainfall, either by direct entry during rains and surface runoff or, more importantly, by phreatic inputs (Dornes et al., 2016). The replenishment of groundwater during wet cycles and its slow circulation and discharge allows many lakes to contain water during parts of the dry periods.

The highest rainfalls occur during the warmer months, with peaks in October and March, whereas rainfall is very scarce during the winter (Casagrande et al., 2006). Summer rains are often torrential (Cano, 1980), leading to substantial variations in both the water level and the extent of many lakes. This was evident for ECA, which was filled at the beginning of the study and reached a depth of $1.60 \mathrm{~m}$ within only one day. Since most of these lakes are located in arheic basins and lack effluent, water loss is mainly a result of evaporation, a phenomenon of importance given the high evapotranspiration that is registered throughout the territory (Roberto et al., 1994). This situation was verified for UTR, since the lake presented a maximum depth of more than $2.00 \mathrm{~m}$ during this study, but in May 2009, after a period of drought, was reduced to $0.35 \mathrm{~m}$ (Echaniz \& Vignatti, personal observation).

The salinity of the studied lakes varied widely, from subsaline to hypersaline environments (Hammer, 1986), but with no discernible regional pattern.

Naturally subsaline lakes, such as OPB exist in La Pampa, and maintain low concentrations of TDSs as their water input is a result of discharges of groundwater retained in dune areas. These lakes therefore, represent temporary ecosystems that can dry out in prolonged drought periods. However, the subsaline lakes LAR and DTO differ from other subsaline lakes because the water 
they receive from the storm drains of the nearby cities has transformed them into permanent lakes (Echaniz et al., 2008, 2012) and has reduced their salinity values, as verified for DTO in a previous study (Echaniz et al., 2008). Something similar has occurred in the hyposaline lake BGI, which was also a temporary and high salinity ecosystem in the past. However, since 2000, this lake has been receiving surplus water from the DTO Lake and waste water from the city of Santa Rosa (Echaniz et al., 2008). Consequently, the lake is now permanent and has increased in volume, while its salinity has decreased and has become more stable (Echaniz et al., 2009).

By contrast, the relatively large hypersaline lake LAM differs from most of the natural lakes in the region. This lake is part of an exorheic river system, with an origin in the Andes and a base level in the Atlantic Ocean, but the river is currently almost inactive (Del Ponti et al., 2015; Echaniz et al., $2015 b)$. In the past, after feeding the group of lakes located in La Pampa (of which LAM is the largest), the surplus water continued on its course to the ocean. Over the past 60 years, however, all the rivers that fed into the system have been dammed in the provinces of Mendoza and San Juan, resulting in extremely sporadic feeding of the lakes. Water enters LAM only on rare occasions, when excessive snowfall in the Andes forces the respective authorities to open the floodgates of the dams. Although this water has relatively low salt concentrations, once the water supply is interrupted, evaporation increases the salinity and leads, on some occasions, to hypersalinity (Del Ponti et al., 2015; Echaniz et al., 2015b). However, this pattern has changed recently, according to former inhabitants of the region, who relate that prior to the cutoff of the river system, the salinity of the lake LAM was considerably lower, and even allowed the occurrence of fish. Among them, Odonthestes bonariensis (silverside) was common and was even the subject of small-scale commercial fisheries (Gilbert \& Gomez, 1985; Carballo et al., 2006; Del Ponti et al., 2015). This is evidence that, in the past, salinity was notably lower and more stable, since this fish species does not tolerate salinity levels higher than those of sea water (Rosso, 2006; Mancini \& Grosman 2008).

Most lakes in La Pampa have not undergone many modifications due to anthropogenic activities, but they remain temporary. The changes in the water level caused by the natural regimen of water influx and drying cause changes in salinity, which, in turn, represent a significant environmental stress for aquatic organisms (Herbst, 2001).
This is the case for the lakes El Carancho and El Destino, which showed salinity levels ranging from 39.91 and $21.90 \mathrm{~g} \mathrm{~L}^{-1}$ in February 2001 to 12.12 and $9.34 \mathrm{~g} \mathrm{~L}^{-1}$, respectively, in November of the same year (Echaniz et al., 2006). More drastic changes have been recorded in La Laura Lake, with salinity ranging from $40.00 \mathrm{~g} \mathrm{~L}^{-1}$ (mesosaline) in February 2001 to $9.23 \mathrm{~g} \mathrm{~L}^{-1}$ (hyposaline) in March 2001 (Echaniz et al. 2006). Similarly, in Utracán, at the time of this study, the average salinity was around $33.00 \mathrm{~g} \mathrm{~L}^{-1}$, but exceeded $100.00 \mathrm{~g} \mathrm{~L}^{-1}$ in May 2009 (Echaniz \& Vignatti, unpublished data), indicating a change from meso- to hypersaline. These types of salinity changes are a part of the natural dynamics of these lakes and complicate their assignment to a specific category of the Hammer's classification system (1986), based on information collected over short periods.

The predominance of $\mathrm{Na}^{+}$in all the studied lakes and of $\mathrm{Cl}^{-}$in seven lakes contradicts the global generalization by Kalff (2002), who indicated that $\mathrm{Ca}^{2+}$ and $\mathrm{Mg}^{2+}$ among the cations and $\mathrm{HCO}_{3}{ }^{-}$and $\mathrm{SO}_{4}^{2-}$ among the anions are that predominate in most of the inner waters of the world. Due to the high $\mathrm{Cl}^{-}$concentrations, the lakes of the Central Pampa resemble lakes in other arid or semi-arid regions, such as those in Australia and Africa (Geddes et al., 1981; Hammer, 1986; Day, 1993; Oduor \& Schagerl, 2007) or North America (Derry et al. 2003). In addition, high levels of $\mathrm{Na}^{+}$ and $\mathrm{Cl}^{-}$are shared with many of the environments of the Chaco Pampa Plains (Drago \& Quirós, 1995; Fernández Cirelli \& Miretzky, 2004) and indicate that the mechanisms controlling the chemistry of these water bodies involve evaporation and crystallization, which are typical processes in arid or semi-arid regions where evapotranspiration rates are higher than rainfall (Gibbs, 1970; Wetzel, 2001; Kalff, 2002; Fernández Cirelli \& Miretzky, 2004). Considering that subsaline lakes with predominance of $\mathrm{HCO}_{3}{ }^{-}$and $\mathrm{Na}^{+}$are in basins formed by the same materials as lakes with higher salinity, their current chemistry are a product of anthropogenic influences that have modified the surrounding landscape and the water input regime (Echaniz et al., 2008, 2009, 2012).

Nutrient concentrations in the studied lakes were relatively high, but they were comparable to those recorded in other parts of Argentina, including some shallow lakes in the province of Buenos Aires, where Quirós et al. (2002) have recorded maximum values of TP and TN close to 8.00 and $28.00 \mathrm{mg} \mathrm{L}^{-1}$, respectively. In contrast to what was found in 
Buenos Aires, where nutrient concentrations were higher in lakes near urban centers (Quirós et al., 2002), in Central Pampa, the largest nutrient quantities, mainly of phosphorus, were found in environments where livestock farming has been carried out for almost 100 years in the basins, but not in the three water bodies near cities, despite the sporadic or permanent release of sewage waste to the lakes (Echaniz \& Vignatti, 2013). This may reflect both the direct contributions of agricultural activities (Hiscock et al., 2003) and the input of cattle excreta during storms (Bremigan et al., 2008; Russell et al., 2008).

The high concentrations of nutrients in the waters of the lakes of the Central Pampa were higher than those reported by Quirós et al. (2002) and Sosnovsky \& Quirós (2006) for lakes in the Humid Pampa, and are some of the highest recorded in the literature. One explanation could be that, in shallow lakes such as those studied, the resolubilization of nutrients from the bottom (internal eutrophication) (Smolders et al., 2006) could be favored by resuspension of sediments caused by the wind (Markensten $\&$ Pierson, 2003; Lövstedt \& Bengtsson, 2008). The sediments of most of the Central Pampa lakes are dominated by sand (Echaniz \& Vignatti, 2013), which has a reduced capacity to adsorb phosphorus and nitrogen (Kapanen, 2008). In addition, the contributions of wild birds, such as swans, herons, or seagulls, can be considerable (Hahn et al., 2008) when added to the impacts of human activities in the basins, such as agriculture, livestock farming, or urbanization.

Despite their high amounts of nutrients, some lakes showed relatively low concentrations of chlorophyll- $a$ and of organic suspended solids, which resulted in high water transparency. In others, the situation was opposite; therefore, two types of lakes could be recognized. The first group includes lakes with a transparency higher than $0.70 \mathrm{~m}$ and low concentrations of chlorophyll- $a$ and suspended solids. These lakes are characterized by their temporality and higher salinity, precisely the environmental conditions that would hinder the establishment and development of a fish fauna. The lack of fish, in turn, would allow the development of large-sized zooplankton, especially cladocerans of the genus Daphnia, with high filtration efficiency, thereby decreasing the overall amounts of phytoplankton. Although species of Daphnia are thought to be relatively scarce in saline environments (Scheffer, 1998), D. menucoensis, a halophilic species typical of the central semi-arid region and northern Patagonia (Echaniz et al., 2006), is frequently encountered in La Pampa. However, in addition to this special importance given to the grazer effect of Daphnia (Muylaert et al., 2006), an equal argument could be made for the relative influence of $M$. eugeniae on the transparency of water in the lakes of La Pampa, since it was the more abundant cladoceran in the three clear lakes; is a relatively large-sized species and is fed into the water column (Vignatti \& Echaniz, personal observation).

The second group of lakes consists of those with a transparency below $0.50 \mathrm{~m}$, due to a strong development of phytoplankton and large amounts of suspended organic solids (LAR, DTO, BGI and $\mathrm{OPB})$. These lakes show the occurrence of fish fauna, especially $O$. bonariensis, a species considered a visual planktivore with a preference for large zooplankton species (Quirós et al., 2002; Boveri \& Quirós, 2002). Predation by this fish reduces the size of the zooplankton of these lakes, resulting in a predominance of small cladocerans such as Bosmina huaronensis, which have low filtration efficiency, and allowing phytoplankton to develop large biomass.

The model of alternative states of shallow lakes has been proposed especially for low salinity environments, and the point has been made that saline lakes would not fit the model because, as mentioned, Daphnia species are scarce at salinities higher than 2.00-4.00 $\mathrm{g} \mathrm{L}^{-1}$ (Scheffer, 1998; Scheffer \& Jeppesen, 2007; Jeppesen et al., 2007). The results obtained here would allow extension of the model to include environments with higher salinities, such as those found in the Central Pampa of Argentina. The point comparison of two studied lakes (EC and BG) would allow synthesis of the top down effect of the trophic cascade (Scheffer, 1998; Boveri \& Quirós, 2002, 2007). Most of the chemical characteristics, such as mean salinity, ionic composition, $\mathrm{pH}$, and nutrient concentration, were extremely similar. However, while the ECA is temporary and was filled at the beginning of the study, BGI is permanent due to the continuous contributions from the nearby city. The temporality of ECA would prevent the establishment of fish populations and therefore allow the development of large zooplankton, with a predominance of D. menucoensis. Grazing of this species would reduce the chlorophyll- $a$ concentration, thereby leading to high water transparency. Conversely, the permanent nature of BGI allows the existence of a population of silversides, whose predation leads 
to the zooplankton of this lake being $30 \%$ smaller than that of ECA and to a scarcity of cladocerans. This, as is shown in PCA analysis (Figure 7), leads to high concentrations of chlorophyll- $a$ and suspended solids, which reduce the transparency of the water to a few centimeters (Echaniz et al., 2010).

Although saline lakes should be turbid, despite having vegetation (Scheffer, 1998; Jeppesen et al., 2007), this study showed a different situation. Transparency was higher in UTR and ECA, which also had a significant coverage of the macrophyte Ruppia cirrhosa than in other lakes of similar salinity (CHA and ESJ), where this macrophyte was not registered. The greater transparency of these lakes could be due to the fact that vegetation, in addition to inhibiting the development of phytoplankton (by allelopathy, competition for nutrients, or shading), would reduce sediment resuspension by reducing the swell (Scheffer, 1998). This was evident since the quantities of suspended solids of $\mathrm{CHA}$ and ESJ were several times greater than those of UTR and ECA.

\section{Conclusions}

Most aquatic ecosystems of the central semi-arid region of Argentina are highly influenced by climatic cycles, which means that under natural conditions they are temporary and have wide variations in water levels and salinity.

Anthropogenic influences have caused some lakes to become permanent due to the discharge from storm and sewage drains, thereby completely altering their chemical composition, salinity, and biota. Conversely, the almost complete human disruption of a river system (a situation that has rarely occurred at the global level) has transformed the lakes of the Chadileuvú-Curacó river system that were once permanent and of relatively low salinity into temporary hypersaline lakes.

The chemical diversity of the studied lakes was relatively low, as only bicarbonated sodic and chloride sodic were found. The dominance of $\mathrm{Cl}^{-}$and $\mathrm{Na}^{+}$indicates that the chemistry of most lakes is governed by the processes of evaporation and crystallization, which are typical of arid or semi-arid regions. The dominance of $\mathrm{HCO}_{3}^{-}$in some lakes could be due to the influence of the urbanization of their basins.

All lakes were hypertrophic, which may be due to the continuous contributions from human activities and wildlife in the basins. On one hand, the high nutrient amounts are the result of processes of accumulation, as the basins are arheic.
On the other hand, they are the result of internal eutrophication produced by frequent sediment resuspensions due to wind effects.

The anthropogenic influence also became apparent as the introduction of predatory fish into permanent lakes modified the structure of the zooplankton community, so that large cladocerans and the high efficiency of filtration are absent or scarce. This, in turn, has led to very low water transparency in these lakes due to high concentrations of phytoplankton chlorophyll.

\section{Acknowledgements}

We thank the Facultad de Ciencias Exactas y Naturales, Universidad Nacional de La Pampa for partial financial support of this project. We also thank the Prato, Deanna, Scheuber, and Fuentes families, owners of the land where EPM, ESJ, BGI, and ECA, respectively, are located for granting access to the study sites. We are also indebted to the Municipalities of General Acha, Santa Rosa, and General Pico for granting access to UTR, DTO, and LAR, respectively, and to the anonymous reviewers whose work improved this article.

\section{References}

AMERICAN PUBLIC HEALTH ASSOCIATION APHA. Standard methods for the examination of water and wastewater. 18th ed. Washington: APHA, 1992.

ARAR, E.J. Method 446.0: In Vitro Determination of Chlorophylls $a, b, c+c$ and Pheopigments in Marine and Freshwater Algae by Visible Spectrophotometry. Washington: U.S. Environmental Protection Agency, 1997.

BOVERI, M. and QUIRÓS, R. Trophic interactions in pampean shallow lakes: evaluation of silverside predatory effects in mesocosms experiments. Verhandlungen des Internationalen Verein Limnologie, 2002, 28, 1-5. http://dx.doi.org/10.1080/0368077 0.2001 .11902661 .

BOVERI, M. and QUIRÓS, R. Cascading trophic effects in pampean shallow lakes: results of a mesocosm experiment using two coexisting fish species with different feeding strategies. Hydrobiologia, 2007, 584(1), 215-222. http://dx.doi.org/10.1007/s10750007-0581-1.

BREMIGAN, M., SORANNO, P., GONZÁLEZ, M., BUNNELL, D., AREND, K., RENWICK, W., STEIN, R. and VANNI, M. Hydrogeomorphic features mediate the effects of land use/cover on reservoir productivity and food webs. Limnology and Oceanography, 2008, 53(4), 1420-1433. http:// dx.doi.org/10.4319/lo.2008.53.4.1420. 
BROCH, E. and YAKE, W. A modification of Maucha's ionic diagram to include ionic concentrations. Limnology and Oceanography, 1969, 14(6), 933-935. http://dx.doi.org/10.4319/lo.1969.14.6.0933.

CABRERA, A. Regiones fitogeográficas argentinas. Buenos Aires: Ed. Acme, 1976. Fascículo 1: Enciclopedia Argentina de agricultura y jardinería.

CANO, E. Inventario Integrado de los Recursos Naturales de la provincia de La Pampa [online]. Buenos Aires: Ed. Instituto Nacional de Tecnología Agropecuaria (INTA), 1980 [viewed 12 Jan. 2019]. Available from: https://recursosnaturales.lapampa.edu.ar//

CARBAlLO, O., DEL PONTI, O., SBROCCO, J., MARANI, J. and CALMELS, A. Laguna La Dulce: características ambientales y aprovechamiento ictícola. In: LA PAMPA. GOBIERNO. SECRETARÍA DE RECURSOS HÍDRICOS DE LA PAMPA, ed. Libro del Primer Congreso Pampeano del Agua. Santa Rosa: Secretaría de Recursos Hídricos de La Pampa, 2006, pp. 165-175 [viewed 12 Jan. 2019]. Available from: http://recursoshidricos.lapampa.gob.ar/images/ pdf_Publicaciones/Libro_Primer_Congreso_del_ Agua.pdf

CASAGRANDE, G., VERGARA, G. and BELLINI, Y. Cartas agroclimáticas actuales de temperaturas, heladas y lluvias de la provincia de La Pampa (Argentina). Revista de la Facultad de Agronomía, 2006, 17(1/2), 15-22.

D'AMBROSIO, D., CLAPS, M. and GARCÍA, A. Zooplankton diversity of a protected and vulnerable wetland system in southern South America (Llancanelo area, Argentina). International Aquatic Research., 2016, 8(1), 65-80. http://dx.doi. org/10.1007/s40071-016-0125-2.

DAY, J. The major ion chemistry of some southern African saline systems. Hydrobiologia, 1993, 267(13), 37-59. http://dx.doi.org/10.1007/BF00018790.

DEL PONTI, O., CABRERA, G., VIGNATTI, A. and ECHANIZ, S. Dynamics of the limnological parameters and zooplankton of La Brava, a shallow lake of the Atuel-Salado-Chadileuvú-Curacó rivers system (La Pampa, Argentina). Applied Ecology and Environmental Sciences, 2015, 3(6), 193-199. http:// dx.doi.org/10.12691/aees-3-6-5.

DERRY, A., PREPAS, E. and HEBERT, P. A comparison of zooplankton communities in saline lakewater with variable anion composition. Hydrobiologia, 2003, 505(1-3), 199-215. http://dx.doi.org/10.1023/ B:HYDR.0000007414.12566.19.

DI RIENZO, J.A., CASANOVES, F., BALZARINI, M.G., GONZÁLEZ, L., TABLADA, M.C. and ROBLEDO, W. InfoStat (versión 2010). Córdoba: Grupo InfoStat, FCA, UNC, 2010.

DOKULIL, M. Climate impacts on ecohydrological processes in aquatic systems. Ecohydrology \&
Hydrobiology, 2016, 16(1), 66-70. http://dx.doi. org/10.1016/j.ecohyd.2015.08.001.

DORNES, P., COMAS, R., CARDÍN, D., POCHETTI, R., IANNI, J. and KRUSE, E. Identificación y caracterización hidrológica de lagunas en el centroeste de la Provincia de La Pampa. In: R. GARCÍA, V. ROCHA and P. DORNES, eds. Actas del IX Congresso Argentino de Hidrogeología, VII Seminario Hispano Latinoamericano sobre Temas Actuales de la Hidrologia Subterrânea. Catamarca: Editorial Científica Universitaria, 2016, pp. 213-220.

DRAGO, E. and QUIRÓS, R. The hydrochemistry of inland waters of Argentina: a review. International Journal of Salt Lake Research, 1995, 4(4), 315-325. http://dx.doi.org/10.1007/BF01999115.

ECHANIZ, S. and VIGNATTI, A. Diversity and changes in the horizontal distribution of crustaceans and rotifers in an episodic wetland of the central region of Argentina. Biota Neotropica, 2010, 10(3), 133-141. http://dx.doi.org/10.1590/S167606032010000300014.

ECHANIZ, S. and VIGNATTI, A. Seasonal variation and influence of turbidity and salinity on the zooplankton of a saline lake in central Argentina. Latin American Journal of Aquatic Research, 2011, 39(2), 306-315. http://dx.doi.org/10.3856/vol39issue2-fulltext-12.

ECHANIZ, S. and VIGNATTI, A. Trophic status of shallow lakes of La Pampa (Argentina) and its relation with the land use in the basin and nutrient internal load. Journal of Environmental Protection, 2013, 4(11), 51-60. http://dx.doi.org/10.4236/ jep.2013.411A007.

ECHANIZ, S., CABRERA, G. and VIGNATTI, A. The ecology of the saline lakes in the semiarid Pampa central (Argentina): limnological characterization and zooplankton of Utracán. Advances in Life Sciences, 2015a, 5(3), 64-72. http://dx.doi.org/10.5923/j. als.20150503.03.

ECHANIZ, S., CABRERA, G. and VIGNATTI, A. Limnological parameters and population structure of Artemia persimilis Piccinelli and Prosdocimi, 1968 (Crustacea, Anostraca) in La Amarga, a hypersaline lake of La Pampa (Argentina). Research in Zoology, 2015b, 5(2), 25-31. http://dx.doi.org/10.5923/j. zoology.20150502.01.

ECHANIZ, S., VIGNATTI, A., JOSÉ DE PAGGI, S., PAGGI, J. and PILATI, A. Zooplankton seasonal abundance of south american saline shallow lakes. International Review of Hydrobiology, 2006, 91(1), 86-100. http://dx.doi.org/10.1002/iroh.200510803.

ECHANIZ, S., VIGNATTI, A. and BUNINO, P. El zooplancton de un lago somero hipereutrófico de la región central de Argentina. Cambios después de una década. Biota Neotropica, 2008, 8(4), 63-71. http:// dx.doi.org/10.1590/S1676-06032008000400005. 
ECHANIZ, S., VIGNATTI, A. and CABRERA, G. Características limnológicas de una laguna turbia orgánica de la provincia de La Pampa y variación estacional del zooplancton. Biologia Acuatica, 2009, 26, 71-82.

ECHANIZ, S., VIGNATTI, A., JOSÉ DE PAGGI, S., PAGGI, J. and CABRERA, G. El modelo de estados alternativos de lagos someros en La Pampa: comparación de Bajo de Giuliani y El Carancho. In: M. DALMASO, C. CAMILETTI and R. HERNÁNDEZ. Libro del $3^{\circ}$ Congreso Pampeano del Agua. Santa Rosa: Base1, 2010, pp. 45-53 [viewed 12 Jan. 2019]. Available from: http://recursoshidricos. lapampa.gob.ar/images/pdf_Publicaciones/Libro_ III_Congreso_del_Agua.pdf

ECHANIZ, S.A., VIGNATTI, A.M., CABRERA, G.C. and PAGGI, S.B.J. Zooplankton richness, abundance and biomass of two hypertrophic shallow lakes with different salinity. Biota Neotropica, 2012, 12(2), 37-44. http://dx.doi.org/10.1590/S167606032012000200005.

ENVIRONMENTAL PROTECTION AGENCY EPA. ESS Method 340.2: Total Suspended Solids, Mass Balance (Dried at 103-105 ${ }^{\circ} \mathrm{C}$ ) Volatile Suspended Solids (Ignited at $550{ }^{\circ} \mathrm{C}$ ). 1993 [viewed 12 Jan. 2019]. Available from: http://www.epa.gov/glnpo/ $1 \mathrm{mmb} /$ methods/methd340.pdf

FERNÁNDEZ CIRELLI, A. and MIRETZKY, P. Ionic relations: a tool for studying hydrogeochemical processes in Pampean shallow lakes (Buenos Aires, Argentina). Quaternary International, 2004, 114(1), 113-121. http://dx.doi.org/10.1016/S10406182(03)00046-6.

GEDDES, M.C., DE DECKKER, P., WILLIAMS, W.D., MORTON, D.W. and TOPPING, M. On the chemistry and biota of some saline lakes in Western Australia. Hydrobiologia, 1981, 82(1), 201-222. http://dx.doi.org/10.1007/BF00048717.

GIBBS, R. Mechanisms controlling world water chemistry. Science, 1970, 170(3962), 1088-1090. http://dx.doi.org/10.1126/science.170.3962.1088. PMid:17777828.

GILBERT, V. and GOMEZ, M. Reconocimiento de los recursos ictícolas de las lagunas: La Dulce, Urre Lauquen y La Amarga. Agro Pampeano, 1985, 2, 40-44.

HAHN, S., BAUER, S. and KLAASSEN, M. Quantification of allochthonous nutrient input into freshwater bodies by herbivorous waterbirds. Freshwater Biology, 2008, 53, 181-193. http://dx.doi. org/10.1111/j.1365-2427.2007.01881.x.

HAMMER, Ø., HARPER, D. and RYAN, P. PAST: Paleontological Statistics Software Package for Education and Data Analysis. Palaeontologia Electronica, 2001, 4(1), 1-9.
HAMMER, U. Saline lake ecosystems of the world. Dordrecht: Dr. W. Junk Publishers, 1986. Monographiae Biologicae, vol. 59.

HERBST, D. Gradients of salinity stress, environmental stability and water chemistry as a templet for defining habitat types and physiological strategies in inland salt waters. Hydrobiologia, 2001, 466(1-3), 209-219. http://dx.doi.org/10.1023/A:1014508026349.

HISCOCK, J., THOUROT, C. and ZHANG, J. Phosphorus budget - land use relationships for the northern Lake Okeechobee watershed, Florida. Ecological Engineering, 2003, 21(1), 63-74. http:// dx.doi.org/10.1016/j.ecoleng.2003.09.005.

JEPPESEN, E., SØNDERGAARD, M., PEDERSEN, A., JÜRGENS, K., STRZELCZAK, A., LAURIDSEN, T. and JOHANSSON, L. Salinity induced regime shift in shallow brackish lagoons. Ecosystems (New York, N.Y.), 2007, (10), 47-57. http://dx.doi.org/10.1007/s10021-006-9007-6.

KALFF, J. Limnology. Inland Water System. New Jersey: Prentice Hall, 2002.

KAPANEN, G. Phosphorus fractionation in lake sediments. Estonian Journal of Ecology, 2008, 57(4), 244-245. http://dx.doi.org/10.3176/eco.2008.4.02.

LÖVSTEDT, C.B. and BENGTSSON, L. The role of non-prevailing wind direction on resuspension and redistribution of sediments in a shallow lake. Aquatic Sciences, 2008, 70(3), 304-313. http://dx.doi. org/10.1007/s00027-008-8047-8.

MANCINI, M. and GROSMAN, F. El pejerrey de las lagunas pampeanas. Análisis de casos tendientes a una gestión integral de las pesquerias. Río Cuarto: Ed. Universidad Nacional de Río Cuarto, 2008.

MARKENSTEN, H. and PIERSON, D. A dynamic model for flow and wind driven sediment resuspension in a shallow basin. Hydrobiologia, 2003, 494(1-3), 305311. http://dx.doi.org/10.1023/A:1025459525880.

MUYLAERT, K., DECLERCK, S., VAN WICHELEN, J., DE MEESTER, L. and VYVERMAN, W. An evaluation of the role of daphnids in controlling phytoplankton biomass in clear water versus turbid shallow lakes. Limnologica, 2006, 36(2), 69-78. http://dx.doi.org/10.1016/j.limno.2005.12.003.

ODUOR, S. and SCHAGERL, M. Temporal trends of ion contents and nutrients in three Kenyan Rift Valley saline-alkaline lakes and their influence on phytoplankton biomass. Hydrobiologia, 2007, 584(1), 59-68. http://dx.doi.org/10.1007/s10750007-0605-x.

PÉREZ, C. Técnicas de análisis multivariante de datos. Madrid: Pearson Educación S.A., 2004.

PONCE DE LEÓN, E. Evapotranspiración. In FUNDACIÓN CHADILEUVÚ, ed. El agua en La Pampa. Santa Rosa: Fondo Editorial Pampeano, 1998, pp. 31-42. 
QUIRÓS, R., RENNELLA, A., BOVERI, M., ROSSO, J. and SOSNOVSKY, A. Factores que afectan la estructura y el funcionamiento de las lagunas pampeanas. Ecología Austral, 2002, 12, 175-185.

ROBERTO, Z., CASAGRANDE G. and VIGLIZZO, E. Lluvias en la Pampa Central. Tendencias y variaciones. San Luis: Centro Regional La Pampa/ INTA, 1994. no. 12.

ROSSO, J. Peces pampeanos: guía y ecología. Buenos Aires, Ed. L.O.L.A. 2006.

RUSSELL, M., WELLER, D., JORDAN, T., SIGWART, K. and SULLIVAN, K. Net anthropogenic phosphorus inputs: spatial and temporal variability in the Chesapeake Bay region. Biogeochemistry, 2008, 88(3), 285-304. http://dx.doi.org/10.1007/s10533008-9212-9.

SCHEFFER, M. and JEPPESEN, E. Regime shifts in shallow lakes. Ecosystems, 2007(10):1-3. http:// dx.doi.org/10.1007/s10021-006-9002-y.

SCHEFFER, M. Ecology of shallow lakes. London: Chapman \& Hall, 1998.

SMOLDERS, A., LAMERS, L., LUCASSEN, E., VAN DER VELDE, G. and ROELOFS, J. Internal eutrophication: how it works and what to do about it a review. Chemistry and Ecology, 2006, 22(2): 93-111. http://dx.doi.org/10.1080/02757540600579730.

SOKAL, R. and ROHLF, F. Biometría. Principios y métodos estadísticos en la investigación biológica. Barcelona: Ed. Blume, 1995.

SOSNOVSKY, A. and QUIRÓS, R. El estado trófico de pequeñas lagunas pampeanas, su relación con la hidrología y el uso de la tierra. Ecología Austral, 2006, $16,115-124$.

VIGLIZZO, E. El agro, el clima y el agua en La Pampa semiárida: revisando paradigmas. Anales de la
Academia Nacional de Agronomía y Veterinaria, 2010, LXIV, 251-267.

VIGNATTI, A., CABRERA, G. and ECHANIZ, $S$. Distribution and biological aspects of the introduced species Moina macrocopa (Straus, 1820) (Crustacea, Cladocera) in the semi-arid central region of Argentina. Biota Neotropica, 2013, 13(3), 86-92. http://dx.doi.org/10.1590/S167606032013000300011.

VIGNATTI, A., CABRERA, G. and ECHANIZ, S. Biology of Boeckella poopoensis Marsh, 1906 (Copepoda, Calanoida) in natural conditions in temporary saline lakes of the central Argentina. Biota Neotropica, 2016, 16(2). http://dx.doi. org/10.1590/1676-0611-BN-2015-0063.

VIGNATTI, A., ECHANIZ, S. and MARTÍN, M. El zooplancton de lagos someros de diferente salinidad y estado trófico en la región semiárida pampeana (La Pampa, Argentina). Gayana (Concepción), 2007, 71(1), 38-48.

VignatTi, A., PAgGi, J., CABRERA, G. and ECHANIZ, S. Zooplankton diversity and its relationship with environmental changes after the filling of a temporary saline lake in the semi-arid region of La Pampa Argentina. Latin American Journal of Aquatic Research, 2012, 40(4), 1005-1016. http://dx.doi.org/10.3856/vol40-issue4-fulltext-16.

WETZEL, R. Limnology. Lake and river ecosystems. San Diego: Academic Press, Elsevier, 2001.

ZAR, J.H. Biostatistical analysis. New Jersey: Prentice Hall, 1996.

Received: 24 April 2017 Accepted: 31 January 2019 